\title{
Multi-level Project Governance: Trends and Opportunities
}

\begin{abstract}
Project governance is important in ensuring successful project delivery. In this article we conduct a systematic investigation of previous research to provide a content-driven review of the literature, and to provide future research direction. We use the textual data mining software Leximancer to identify dominant concepts and themes underlying project governance research. Our findings indicate that agency and stakeholder theories have been adapted to the project governance context to a greater extent than other theories. Furthermore, we find differences in project governance research, published in project management journals compared to general management, IT and engineering journals. We conclude the paper by presenting a framework that links governance theories to the multiple organizational levels relevant to project governance.
\end{abstract}

\section{Introduction}

The use of projects by organizations has evolved from simply being a tactical tool—for example, to manufacture products and service-towards becoming a strategic vehicle to transform organizations. Accordingly, much academic and practitioner attention has been dedicated to better understanding the management and governance of projects. Project management is mainly concerned with the operational control and execution of daily work at the project level (Turner, 2009), whereas project governance represents a higher-level structure; defining processes and structures to govern multiple projects and to manage strategic objectives (Nielsen, 2010). Previous studies have provided us with valuable insights into specific aspects of project management, such as leadership and performance outcomes (Turner, 2009). However, as the call for papers for this special issue on "Transforming Governance in Complex Project Environments" in the International Journal of Project 
Management indicates, research has thus far devoted relatively less research attention on how to best govern projects.

On its most basic level, project governance supports an organization in aligning its project objectives with its organizational strategy, achieving set project objectives and monitoring performance. It also describes the means for attaining such objectives (PMI, 2013, p. 579; Turner, 2009, p. 311). Project governance is an overarching business function in project-based organizations (PBOs) (PMI, 2013) and provides a framework for organizational processes, decision-making models and project management tools, which support the successful delivery of projects, programs and portfolios. It is thus closely linked to performance and represents a critical cornerstone of PBOs across multiple organizational layers, especially in complex projects (Garland, 2009). Governance research has started to acknowledge and address the particular nature of governance across the various relevant organizational levels (e.g., Foss et al., 2010). Due to the multiple definitions of project governance found in literature, the exact nature of the construct remains unclear.

To provide structure and direction to existing and future research on project governance the specific aims of this paper are as follows. First, we identify and systematically review 97 papers published in major management (62 articles) and three project management (35 articles) journals, to explore the status of project governance research using unstructured ontological discovery (text mining). By so doing we explore the dominant content themes of project governance research. We also compare whether the content themes differ between research published in traditional management journals and dedicated project management journals. Second, we investigate how concepts and themes of dominant corporate governance theories (i.e., agency, stakeholder, stewardship and resource dependence theories, as well as transaction costs economics) have been applied to the context of project governance. Third, 
we propose future research directions by presenting a framework with a particular focus on linking governance theories with the different levels of foci in project governance.

Our study uses scholarly articles and thus, the words of contributors to the field, to scientometrically analyze project governance. We use the textual analysis tool Leximancer, as it is a powerful device for interpreting and visualizing complex text data (Campbell et al., 2011). Leximancer investigates the co-occurrence of words within their textual contexts, which provides valuable insights for the narrative inquiry of the project management research field. The idea is that a word is defined by the context within which it occurs and words that co-occur reflect categories (i.e., concepts) with specific meaning. Based on the words of the authors, Leximancer enables us to identify concepts and themes in the field. Consequently, it is these text-derived concepts and themes that represent our level of analysis, rather than the article or author as used in other bibliometric techniques, such as co-citation analysis.

The remainder of this paper is structured as follows: we begin with a concise overview of the key theories that underlie corporate governance research; provide a short introduction to project governance research, as well as to the multi-level nature of PBOs, and we follow with an outline of our research methodology and data sets that constitute the basis for our detailed analysis of project governance research. Following the presentation of the Leximancer-derived results, we conclude this paper with a summary of our findings and provide avenues for future research through introducing a conceptual research framework, which discusses governance theories applied to the various organizational levels in PBOs.

\section{Theoretical background}

\subsection{General governance theories}

Management scholars have drawn, and considerably adapted, ideas from policy research in political science to develop theories explaining the good governance of corporations (Bevir, 
2010). ${ }^{1}$ In its most general form corporate governance is defined as the set of rules, (stakeholder) relationships, systems and processes by which authority is exercised and controlled in organizations. Corporate governance influences how organizational objectives are set and achieved (ASX, 2007; OECD, 2004) and also fosters self-regulation within a greater context, without determining every action of organizational actors (Clegg et al., 2002). Hence, "governance is ultimately concerned with creating the conditions for ordered rule and collective action" (Stoker, 1998, p. 155). In what follows, we provide a concise overview of the dominant governance theories and summarize them in Table 1.

\section{Insert Table 1 here}

Agency theory Agency theory assumptions have been highly influential in shaping corporate governance systems and follow a 'traditional' finance and economics perspective (Eisenhardt, 1989). Agency theory implies that the principal has difficulties in motivating the agent to act in the principal's best interests. A common example is the separation of ownership and control, which is a fundamental problem in organizations (Jensen and Meckling, 1976). This separation is the result of absent or distant owners/shareholders (i.e., principals), employing professional executives (i.e., agents) to act on their behalf (Eisenhardt, 1989). As principals need to provide agents with some level of decision-making authority, issues related to conflict of interest and moral hazard, due to asymmetric information, may arise (Williamson, 1988). In line with neo-classical economics, the fundamental assumption underlying this theory is that an agent may be self-interested and act opportunistically, rather than purely in the interest of the principal/s (Donaldson and Davis, 1991). Furthermore, agents and principals may differ in their risk attitudes (Eisenhardt, 1989). To mitigate these

\footnotetext{
${ }^{1}$ Please see Bevir (2010) for more information on the difference of governance research in political science.
} 
problems, the principal will incur 'agency costs' (Jensen and Meckling, 1976). These costs arise from the need to create outcome-based incentive systems that enable the alignment of agents' and principals' interests (e.g., performance-based contracts). Furthermore, costs arise from implementing monitoring and control mechanisms to govern agent behavior and to prevent agents' abuse of principals' interests. In the context of project management this theory is particularly used to describe the relationship between the owner of a project and its manager (Turner et al., 2010).

Transaction cost economics Transaction cost economics (TCE) is concerned with the possibility of opportunistic behavior eventuating, which may be caused by organizational actions being driven by self-interest and an ambition to minimize costs (Williamson, 1979). In order to minimize the total costs of a good or service, different costs (e.g., production, search or information) must be taken into account before making a decision about suppliers, outsourcing, mergers and acquisitions, and any coordination between firms such as alliances or contractual agreements. TCE can, therefore, help to understand governance and organizational decision making. In its original form, Williamson (1975) outlines three drivers of transaction costs: (i) contingency factors (e.g., frequency and asset specificity); (ii) behavioral factors (e.g., bounded rationality and opportunism), and (iii) context (i.e., institutional context). An organization's ability to control and/or decrease the impact of these factors - through contractual agreements, risk sharing or alliances — can minimize transaction costs and consequently determine an appropriate governance structure (Winch, 2001). In the project governance context, this theory may, for example, be used to describe the process of selecting contractors and suppliers (Winch, 2001).

Stakeholder theory Stakeholder theory challenges agency assumptions about the primacy of shareholder interests and is based on a socially-oriented perspective (Jones and Wicks, 1999). It argues that a company should be managed in the interests of all its 
stakeholders, such as employees, suppliers, customers, local communities and the environment, as well as society at large (Blair, 1995). Stakeholder theory, therefore, suggests that conflicting interests and claims of different organizational stakeholders need to be balanced (Donaldson and Preston, 1995). These claims can range from purely financial objectives (e.g., return on investment) to corporate social performance measures (e.g., the organization's attractiveness as an employer and its generation of goodwill). Meeting the interests of all stakeholders can be challenging, since social goals have the potential to constrain financial performance. Hence, the underlying governance mechanisms must find a way to balance this paradox. In stakeholder theory, performance depends on the organization's understanding of: key business and competitive drivers; its capacities for strategic thought, and its communication and leadership skills in relation to all stakeholders. Following stakeholder theory, project governance is an essential strategy to assist project teams understand, and respond to, various stakeholder groups.

Stewardship theory Stewardship theory provides an alternative description of human behavior compared to agency theory and is rooted in psychology and sociology. It assumes that not all human behavior is dictated by self-interest but that some organizational members (stewards) exhibit 'pro-' and collectivistic rather than individualistic and self-serving behavior (Davis et al., 1997). These stewards do not act in mere self-interest even where the interests of the steward and the principal are not aligned, which provides a basis for relational governance mechanisms (Davis et al., 1997). Stewardship theory argues that both parties have an interest in building and maximizing upon long-term and beneficial company relationships where motives and aims are well aligned between stewards and shareholders. More particularly, stewardship theory opposes agency theory as it assumes individuals perceive greater value in cooperative behavior (Donaldson and Davis, 1991). A steward believes that his or her value is increased and secured when the organization is performing well. Hence, stewards seek to improve organizational performance in order to ultimately improve their own situation. The 
main concepts of stewardship theory are, therefore, identification, intrinsic motivation, longterm involvement and trust (Davis et al., 1997). Stewardship theory, applied to the context of project governance, proposes that shareholders would best be served by empowering project managers.

Resource dependence theory Resource dependence theory (Pfeffer and Salancik, 1978; Thompson, 2011) offers valuable insights into the allocation, prioritization and facilitation of organizational resources (Oliver, 1991), and suggests that organizational success depends on the organization's ability to control interdependent external and internal resources (Clarke, 2004). A firm's resource base provides crucial connection points when organizations engage in exchanges and transactions, and thus plays a vital role in achieving organizational success (Pfeffer and Salancik, 1978). Resources can take a variety of forms all of which can be argued to add to the 'capital' of a company. The variety of available resources (including human resources) can be unique to an organization, and in turn, affect its organizational governance structure (Hillman and Dalziel, 2003). Resource dependence theory allows us to think of the varied needs that organizations have at different stages of their life cycle and how resources can be used to overcome organizational challenges. Simply put, resource dependence theory views resources as the main driver of an organization's governance structure. Consequently, this governance theory may help to understand the importance of allocating and prioritizing different resources that are often shared across project programs and portfolios.

The corporate governance literature has acknowledged the plurality of theoretical governance frameworks (Clarke, 2004). Existing corporate governance theories are context dependent, not universally applicable and can be applied to project governance in particular contexts, settings or situations. Although some authors argue for the convergence of existing governance theories (Roe, 2003), we believe that keeping the plurality and differences of existing governance theories is more beneficial, as it enables us to specifically account for the 
distinct needs across organizational levels, projects, programs and portfolios to ensure successful project governance.

\subsection{Overview of project governance research}

Several definitions of project governance exist (Table 2) and they each share the views that project governance is primarily concerned with aligning project objectives with an overarching organizational strategy, and that it is necessary to create stakeholder benefits across different organizational levels. In general, project governance is concerned with consistently delivering successful and satisfactory projects, and programs, in regards to "their planned contribution to corporate strategy and stakeholder expectations" (Müller, 2009, p. 16). Projects are embedded across multiple organizational contexts (Sydow et al., 2004). Hence, in order to achieve organizational and project objectives, conceptualizations of project governance need to take into account this multi-level nature, which occurs at the intersections of projects, programs, and project portfolios.

Insert Table 2 here

Moreover, projects are used as the main vehicle to achieve strategic objectives and beneficial change (Turner, 2006). To allow for repeatable, effective and successful completion of projects and organizational objectives, project-based organizations (PBOs) often use formal organizational governance processes and mechanisms. These mechanisms might be different across different layers within PBOs, since the specific objectives at each level may be distinct (Söderlund, 2011; Turner et al., 2010). Despite possible differences, governance frameworks implemented at different organizational layers cannot be seen as independent operating systems. They are interrelated across the different layers of the PBO and, for example, a higher-level governance structure can impose constraints on a lower 
organizational level. This is particularly the case when a PBO is subject to strict organizational governance. It is therefore important to account for the multi-level nature of PBOs and briefly outline the characteristics of governance across different organizational layers within the PBO.

To obtain an understanding of the status of the current project governance literature we investigated management and project management literature, using Leximancer, a textual analysis tool. This enabled us to inductively identify which governance theories were most widely used across the literature. In the following section we provide an overview of the dataset and describe our methods in further detail.

\section{Research Methods}

\subsection{Data}

Project management has gained interest from a wide range of disciplines, including engineering, information technology, research and development, and management (Figure 1). We focused on academic journals because, while novel research may be published in books and conference proceedings, journals remain the premium outlet for research aimed at scholarly advancement (Hällgren, 2012; Pfeffer, 2007). Articles on project management related topics were found in journals ranging from broader management and organization studies (e.g., Academy of Management Journal, Organization Studies), to project management-specific outlets (e.g., International Journal of Project Management). We used the Scopus database to identify papers that deal with project governance. To achieve the most relevant sample of project governance-related articles-published in management, engineering, IT, science and decision science journals - we only downloaded articles that 
used the term 'project governance' in their title, abstract and/or keywords. This search resulted in 87 papers out of which we had access to 62 articles. $^{2}$

Insert Figure 1 here

In a second step, we downloaded another set of articles on project governance, which were published in the major project management-specific journals (i.e., International Journal of Project Management (IJPM), Project Management Journal (PMJ)), to compare governance-specific literature to general project management literature. The related journals represent the current formalized, discipline-specific theoretical knowledge base. To compile the most representative sample we searched for the term 'governance' in the title, abstract, and/or keywords, as articles published in dedicated project management journals deal with projects by their very nature. Our search resulted in 44 papers out of which we had access to 35 articles. ${ }^{3}$ Table 3 provides a summary of the project management-specific papers.

\section{Insert Table 3 here}

\subsection{Method}

To systematically review existing research on project management, we used the textual analysis tool Leximancer, as it is a powerful means of interpreting and visualizing complex text data (Campbell et al., 2011). Unlike the more common co-citation analysis, which uses the links between authors rather than key constructs as the primary unit of analysis, our primary interest was to uncover the links between constructs that are used within the project management research stream. The co-citation analysis method is aimed at determining the

\footnotetext{
${ }^{2}$ The remaining papers were either forthcoming or not available online. We also excluded all literature from project management-specific journals (e.g., IJPM, PMJ) as they are part of the second analysis.

${ }^{3}$ The remaining papers were either forthcoming or not available online.
} 
subject similarity between articles, based on the logic that when articles are published within a particular research stream, they are assumed to address similar topics (White and Griffith, 1981). In our study, we investigated the co-occurrence of words within their textual contexts, which provides valuable insights for the narrative inquiry of the project management and governance research fields. The rationale for this assumes that a word is defined by the context within which it occurs, and words that co-occur reflect categories (i.e., concepts) with specific meanings. We perform unstructured ontological discovery using Leximancer 4.0 (www.leximancer.com). Leximancer enabled us to review the actual words of authors and, thus, to identify concepts and themes emerging from existing literature. Consequently, it is such text-derived concepts and themes that represent our level of analysis, rather than the article or author as used in other bibliometric techniques, such as co-citation analysis. Leximancer has successfully been used in similar research contexts to scientometrically describe and analyze text (e.g. Dann, 2010; Liesch et al., 2011), for example: decomposing the international business field (Liesch et al., 2011); corporate risk management (Martin and Rice, 2007); tourism (Scott and Smith, 2005), and behavioral research (Smith and Humphreys, 2006).

Leximancer runs both conceptual and relational analyses of textual data and then provides visual representations of these analyses. Thus, it allows researchers to examine concepts (i.e., common text elements) and themes (i.e., groupings of uncovered concepts) used by other scholars (Mathies and Burford, 2011). To do so, a machine-learning algorithm is applied to uncover the main concepts used in text and how they relate to each other (Campbell et al., 2011). Leximancer-derived concept identification exhibits high face validity, that is, close agreement with expert judgment (Rooney, 2005). Additionally, the program is appropriate for exploratory research as it produces high reliability and reproducibility of concept extractions and thematic clustering, without facing some of the possible biases that 
are characteristic of manually coded text analyses techniques (Baldauf and Kaplan, 2011; Dann, 2010; Smith and Humphreys, 2006).

The maps of meaning (Figures 2-3) are derived by the Leximancer software, based on the frequency counts of individual concepts and their proximity to each other within text. Leximancer initially creates a thesaurus of words that are closely related to a concept (refer to dots in Figures 2-3) to define its content. Leximancer's derived concepts are collections of words that carry related meaning/s (Campbell et al., 2011). Relationships between concepts are then identified and aggregated into themes (refer to circles in Figures 2-3) ${ }^{4}$. The importance of themes is expressed by the color of the circles (brighter circles are more important) and circle size (the size indicates how many concepts have been clustered together). The distance between concepts on the 'maps of meaning' show how closely the concepts are related. Therefore, concepts that are weakly related, semantically, will be mapped far apart (Campbell et al., 2011; Rooney, 2005). When concepts and themes appear close together within the textual data, they will be clustered close together or even overlap in the map (Campbell et al., 2011).

The algorithm applied by Leximancer is Bayesian, and based on its Bayesian logic the software is capable of automatically and efficiently learning that words forming a sentence predict emerging concepts. This can be achieved across a great number of concepts and a large corpus of text. Concepts are defined in advance by using only a small number of seed words. As numerous trials have shown, Leximancer's automatic selection of key concepts and themes within text data exhibits good agreement with expert judgments (Campbell et al., 2011; Rooney, 2005). In the proceeding section we illustrate our analysis and report on results.

\footnotetext{
${ }^{4}$ We deleted words such as 'authors', 'example', 'use', etc. from the text so as to not bias the creation of concepts and themes.
} 


\section{Results and analysis}

Our research depicts the nature of project governance research, based on the words of the authors who are active in the field of project management. The analysis of the data is outlined below. First, we analyzed the 62 articles across the 21 non-project management-specific journals, which include the terms 'project governance' in their title, keywords and/or abstract. We then focused our analysis on 34 articles that include the search term 'governance' and were published in leading project management journals. In the following section we present the main findings from our data analysis.

\subsection{Project governance in non-project management literature}

The results of the textual analysis of the 62 papers, of the first dataset (Figure 2), show that 'governance' and 'project' are the most central and dominant themes in previous research (depicted by bright colors). When looking at the concepts (black dots), which form the Leximancer-derived governance theme, in more detail we find that 'structure', 'process' and 'role' are closely related, indicating that the general objective of project governance is to propose a framework that combines processes, roles and accountabilities aimed at delivering projects. Moreover, we find that 'level' appears as a concept within the governance theme, indicating that project governance issues are discussed in relation to different levels in the governance literature.

The 'project' theme comprises concepts, such as 'success', 'business', 'management', 'change' and 'implementation'. These concepts indicate an understanding of projects as vehicles in organizations that can implement change (Cicmil, 1999). This particular perception of projects is primarily used in the general management literature - as projects are considered to be parts within a greater organizational structure and not as self-sufficient organizational entities (e.g., temporary organizations) that possess their own organizational identity. The 'management' concept indicates a distinct focus on project management, as 'management' is part of the 'project' theme. 'Governance' appears as an independent theme 
and is in close proximity to the concepts of 'project' and 'organization'. This relationship supports our argument for the multi-level nature of project governance, which provides an organizational structure across different organizational layers. Project management, in contrast, deals predominantly with the tactical, daily activities of delivering successful projects, and is thus situated on a lower level, such as the project (O'leary et al., 2011).

Insert Figure 2 here

There is great overlap of the 'governance' and 'control' themes, indicating that concepts relating to these themes are frequently mentioned together within articles. This reinforces the traditional perception of governance as an organizational tool for monitoring and controlling managerial actions (Garland, 2009). Interestingly, the terms 'mechanism' and 'performance' form part of the 'control' theme, rather than the 'governance' theme, and therefore shows a strong relationship between performance and control. Control mechanisms, to manage and govern projects on a higher level, have been proposed by governance scholars (e.g., Müller 2009, Davis et al. 1997) as a means of creating visibility and transferability of organizational practices across different organizational layers and departments. We also find the concepts of 'contract' and 'formal' (together with the performance measures of 'cost' and 'quality') in the 'control' theme. The interplay between contracts and performance is an underlying feature of agency theory, which describes contracts as a mechanism for effectively delivering projects, as they regulate the potential misalignment of interests and trust between principals and agents.

The 'knowledge' theme and its overlap with the 'governance' theme show the relevance of knowledge for PBOs. For example, previous research has investigated the governance of knowledge creation and dissemination in inter-organizational projects (BoschSijtsema and Postma, 2010). Sydow et al. (2004) further point out that 'knowledge' in a PBO 
context is relevant within project teams, between project teams, at the organizational and inter-organizational levels. This is supported by our Leximancer analysis (see Figure 2), as the 'knowledge' theme comprises concepts such as 'actors', 'network', 'market' and 'organizations', which describe the organizational context in which knowledge is discussed. This suggests a research focus on the various levels of analysis relevant to project governance. As stated above, governance can occur on multiple organizational levels, but is mainly set out on a higher organizational level to ensure successful project delivery. These indicate a focus on structural (e.g., network) and non-structural (e.g., activities) issues. This dual focus implies a more holistic view that challenges the traditional notion of organizations as rational constructs - a perspective that, with the emergence of alternative management and project studies, has gained prominence over the last decade (e.g. Hodgson and Cicmil, 2006; 2008).

The 'resource' theme is also in close proximity to the 'governance' theme. The facilitation, prioritization and allocation of organizational resources are three mechanisms that underpin good project governance (Abednego and Ogunlana, 2006). This importance of resources is specifically supported by the resource dependency theory, a corporate governance theory that is entirely concerned with organizational resources and their imperative contribution to organizational and project success. Moreover, project governance and project management have been described as being primarily concerned with organizational processes (e.g., best practices) and the human ability to apply such processes to the delivery of successful outcomes. In other words, projects are mainly driven by people, that is, their intellectual capacity and individual development, and their selection of appropriate modes of doing. This highlights the existence of a variety of resources, such as human and technical, all of which require to be integrated when delivering a successful project (Müller, 2009). Hence, an important aspect of delivering a successful project is the facilitation and allocation of existing organizational resources, particularly across project programs and portfolios. As 
Turner and Keegan (2001) outline, there are also examples of project managers being evaluated on their resource utilization rather their profit generation. This becomes increasingly important, and problematic, in large and complex projects where projects share common resource pools - both physical and human - and the level of uncertainty is exponentially higher.

The 'community' and 'social' themes illustrate the importance of contextual and environmental factors that enable, but also restrict, the successful delivery of projects and programs (Müller, 2009). These themes focus on the social and behavioral aspects of project governance, and the context in which projects are delivered. This is highlighted by concepts such as 'people', 'social', 'politics' and 'power'. The term 'relational governance' is often used to describe this form of governance, in which arrangements based on trust complement complex contracts (Poppo and Zenger, 2002). Hence, relational governance and the concepts outlined in the 'community' and 'social' themes describe the importance of the behavioral aspect of projects, emphasizing non-technical aspects (Pollack, 2007). Behavioral aspects have gained prominence over the last decade, with the emergence of critical project studies (Hodgson and Cicmil, 2006; 2008), where the focus is on relationship and interpersonal relations, such as relational contracts which are based on trust and a collaborative mind set regarding shared risk and reward (Baker et al., 2002). The concept of 'community' implies a more holistic view that stretches across levels, which is particularly relevant in the context of project governance (Piattoni, 2010). This theme further demonstrates that 'participation' is an underlying concept that indicates a need to involve stakeholders-as well as encourage their active participation - by expressing expectations, discussing and correcting requirements, and iteratively working towards successful outcomes (London and Siva, 2011).

The 'planning' theme represents the context in which project governance has been researched. Planning, as a managerial action, is a vital component of many governance 
frameworks and their quest for rigorous planning and control mechanisms, and could thus be expected to appear closer to concepts such as 'control', 'mechanisms', or 'framework'. Interestingly, urban planning projects seem to be a prominent context in which project governance has been investigated. The proximity of the concepts 'urban' and 'planning' provides the basis for this argument. The appearance of the concepts 'private' and 'public' indicates that both types of projects were used for empirical evidence, in addition to there being a particular focus on Public Private Partnerships (PPP) within the governance context (e.g., IJPM 2006, Issue 24).

In summary, our analysis of the general management literature indicates that agency theory plays a prominent role in describing project governance. Moreover, resources emerge as a dominant theme in the governance literature, indicating a link to resource dependence governance theory. Moreover, we argue that the existence of social aspects in combination with the 'community' theme indicates a particular focus of behavioral governance theories (e.g., stakeholder theory), despite the fact that the term 'stakeholder' does not specifically appear in our results. In the following section, we will investigate project governance-related articles in project management-specific journals, to clarify whether different theories and contexts are used to conceptualize project governance.

\subsection{Project governance in project management literature}

In a second analysis step we focused on 35 articles that were published in dedicated project management journals (Figure 3). Overall, the results show a strong research focus on the themes of 'project' and 'management' (bright colors). 'Governance' is only a concept within 'management'. The 'project' and 'management' themes are the most dominant themes and indicate that projects have mainly been discussed together with concepts such as 'change', 'information', 'governance', 'stakeholders', 'strategy' and 'performance'. Performance has traditionally been associated with good project management and governance (Turner, 2009), 
which is highlighted by the existence of the concept 'performance', but also by its proximity to the concept of 'governance'.

Insert Figure 3 here

The large overlap of 'project' with the theme of 'development', which includes 'value' as an individual concept, highlights the inclusion of performance measures beyond the traditional iron triangle (Atkinson, 1999) — a crucial aspect of stakeholder theory. The purpose of stakeholder governance is to provide value for all stakeholders (Clarke, 2004), which transcends the more narrow view of shareholder theory. Stakeholder theory argues that organizational and project objectives (e.g., financial, growth and social performance) must be developed by "balancing the interests and claims of different stakeholders, such as managers, employees, suppliers and the wider society" (Müller, 2009, p. 5). The 'development' theme is further comprised by the concepts 'system', 'support' and 'structure', which are also in close proximity to the concepts 'governance' and 'management', and thus emphasize the importance of developing an organizational governance structure that aims to support the daily management of projects, programs and portfolios.

The concepts 'change' and 'strategic', within the 'project' and 'management' themes, indicate a particular focus on strategic issues in which projects are seen as vehicles of change that enable organizations to achieve their strategic objectives (Artto et al., 2008). Traditionally, strategy has been discussed as a higher-level concept, but the increasing size and complexity of projects requires that projects themselves also be set up strategically (Artto et al., 2008). Hence, project strategy is a dual level phenomenon that, in different contexts, is characterized by the strategy of a project-based parent organization or several strong stakeholders, and different degrees of project independence in which projects have a particular strategic focus of their own. 
Moreover, the 'management' theme specifically comprises concepts such as 'stakeholder' and 'manager', indicating a general relationship between project governance and management, as governance structures position different roles, processes and accountabilities in place. Governance frameworks provide the boundaries and rules in which the project-level actor (e.g., project manager) can freely act to produce value for the various stakeholders. The importance of 'stakeholder' indicates a particular importance of behavioral aspects in project management, as suggested by the stakeholder theory. Stakeholder theory conceptualizes organizations as a system of stakeholders, across multiple levels and with multiple degrees of involvement. That is, stakeholders may include shareholders, the wider society, organizational actors and other beneficiaries. Although some managers only focus on a narrow group of key stakeholders, others focus on a wide array of stakeholders, including the public (e.g., corporate social responsibility). Stakeholder theory, therefore, aims to enable coordination of information and activities between different stakeholders in order to create value for all the relevant parties (Müller, 2009).

Governance is a multi-level phenomenon that facilitates interactions between organizational actors within and across organizational levels. Trust plays a critical role in governance literature with regards to managing the relationships between various actors (Poppo and Zenger, 2002). This connection is illustrated by the concepts 'trust' and 'relationship' within the 'actors' theme, which are of particular interest in agency and stewardship theory (Chiles and McMackin, 1996). While both governance theories approach the concept of 'relationship' differently, they both outline the common goal of delivering a beneficial outcome for stakeholders (Zaheer and Venkatraman, 1995). Agency theory, on the other hand, achieves this via physical contracts while stewardship theory argues that relational governance is the key to success, as "relational exchanges persist over time to yield enhanced rents for both partners" (Singh and Sirdeshmukh, 2000, p. 153). 
Similar to the content of the 'knowledge' theme in our analysis of project governance in non-project management literature (see Figure 2), the 'organizations' theme acknowledges a higher organizational level that defines the organizational frame in which project governance takes place. This higher organizational level is more concerned with organizational structures (i.e., 'process' and 'practices'), the larger context and its characteristics (i.e., 'complex' and 'environment'), as well as the continuous improvement of existing organizational capabilities (i.e., 'learning' and 'knowledge'). For instance, Pemsel and Muller (Pemsel and Müller, 2012) investigated knowledge governance practices and show that governance mechanisms impact knowledge creation in PBOs.

The 'construction' and 'public' themes generally describe the research contexts in which project governance research takes place (e.g., public and private sectors, government and the investment sector). Furthermore, the concept of 'contracts' appears in the 'construction' theme and is in proximity to concepts such as 'client', 'cost' and 'time', which indicates that contracts are primarily used in combination with performance measures. Performance-based contracts are directly related to agency theory and transaction cost economics, both of which have traditionally been used to explain the governance of projects (e.g., Söderlund, 2011; Turner and Keegan, 2001; Winch, 2001), in a construction context that is primarily driven by engineering-based approaches to project management.

Moreover, 'risk' appears as a concept within the 'public' theme and illustrates that project management journals have discussed project governance to a large extent in the context of risk, as governance structures are particularly necessary in risky and more complex projects (Abednego and Ogunlana, 2006). These types of projects (e.g., megaprojects) require sophisticated governance mechanisms that manage and control projects while meeting the expectations of various stakeholders (Aaltonen and Sivonen, 2009). For example, an efficient governance structure provides a structure in which badly performing projects are highlighted 
and early warning signs trigger an alert mechanism. Hence, risk management is a key aspect of project governance, and therefore, in close proximity to the concept of 'performance'. Furthermore, 'risk' is a common theme in agency theory, specifically with regards to the potentially different attitudes towards risk between principals and agents (Eisenhardt, 1989).

\section{Discussion}

Our analysis of extant literature illustrates that research on project governance, in management journals and project management journals, reveal a variety of concepts and themes underlying existing governance theories. One major finding is that project governance research in broader management, engineering and IT journals specifically deals with the concept of governance, whereas project management journals are more concerned with the aspect of project management. Furthermore, we find that not all existing governance theories have been applied to the project governance context, or if they have, not to the same extent. While both sets of journals contain a variety of governance theories, resource dependence theory appears to only have had a major influence on research in non-project management journals. Furthermore, concepts such as 'organization', 'project', 'manager' and 'level' indicate that project governance is a multi-level phenomenon. Additionally, concepts such as 'roles', 'actor', 'contract' and 'relationship' suggest that project governance is an organizational control mechanism, which uses formal and informal structures, to govern accountabilities and responsibilities across different organizational levels, both internally and externally (e.g., 'contractors' and 'clients').

Some of the confusion around project governance research may have arisen due to researchers attempting to apply various governance theories in order to find a single solution to the problem of project governance. However, the findings from the textual analysis indicate that project governance is a multi-level phenomenon. That is, that different levels of analysis require different governance models and underlying mechanisms rely heavily on assumptions 
about the organizational context, as well as the nature of projects and the way in which projects operate (O'Leary, 2012). Therefore, in the remainder of this paper we present a conceptual framework, structured around the different levels of governance, that provides suggestions regarding how existing governance theories may best be applied to the context of project governance (Table 4).

Insert Table 4 here

\subsection{Level of project}

At the individual project level, project governance is mainly concerned with ensuring that "projects are undertaken in the right way to deliver the right products, and to ensure the products will deliver the desired benefits" (Turner et al., 2010, p. 112). Project governance is, therefore, closely related to project management by setting the overarching frame in which the management of projects occur (PMI, 2013). This frame comprises several governance mechanisms imposed by higher project based organization PBO levels (Müller et al., 2013), such as structural control and planning mechanisms, and relational mechanisms — such as trust and empowerment (Zaheer et al., 1998). Project governance on a project level has a direct effect on project management and the delivery of project-specific objectives to a broader set of stakeholders (Bredillet, 2008c). Project management is thus a component of project governance at the project level that deals with the operational control and execution of the daily project work on the project level (Turner, 2009). In other words, project management is primarily concerned with meeting the tactical objectives of a particular project (PMI, 2013). Successful projects contribute to the broader strategic goals on a program or portfolio level of the PBO (Williams and Samset, 2012). 
At the project level, the main objectives and performance measures are rather short term and goal oriented, aligned with the nature of the particular project. In this context, transaction cost economics (TCE) and agency theory are useful frameworks to explain and analyze project governance, at the project level, which is also supported by our analysis of the project management-specific journals. Both theories are well aligned with the needs and nature of an individual project. For example, TCE research in project management may explore the impact of transaction costs (Williamson, 1998; 1979) and costs of alternative forms of contracting. The total costs are the sum of the actual production cost (i.e., rate of the contractor), in combination with the cost of governing the transactions implicit in that choice of production technique (i.e., overall product provided by contractor). A particular production technique that has the lowest production costs might, therefore, not be the economizing choice if transaction costs are also considered (Winch, 2001). Project management literature has primarily used construction projects to investigate this type of governance (Winch, 2001) and the effects that TCE has on the underlying roles and responsibilities in projects (Turner and Keegan, 2001).

Moreover, agency theory in project management investigates the interplay between projects and the external environment, such as project managers and project owners, specifically with regards to goal preferences and information asymmetry (Söderlund, 2011). Agency theory assumes that behavior belongs to that of a rational actor who acts in a selfserving and self-interested way (Jensen and Meckling, 1976). To protect the organization's (i.e., shareholder's) interests, agency theorists prescribe various governance mechanisms to align agent behavior with the interests of principal/s (Davis et al., 1997). For example project owners may keep potentially self-serving project managers in line by performing project audits and performance evaluations. These controlling governance mechanisms are installed due to the underlying assumption that the agent (i.e., project manager) will act in a selfinterested fashion in order to maximize his or her individual utility, at the expense of the 
principal's utility (Davis et al., 1997). Due to the prominent nature of projects as temporary organizations, which imply short-term and goal-oriented mind sets, it is not surprising that agency theory and TCE are perceived as the dominant governance streams across project management literature.

\subsection{Level that links parent organization to project (e.g., PMO)}

At this middle level within PBOs, project governance has the main task of linking corporate governance to the governance of a particular project, and is concerned with two key issues: (i) defining the objectives of projects, program and portfolios, and (ii) defining the project management capabilities by which the projects are delivered (Turner et al., 2010). This level is often represented by a project management office (PMO), which is defined as an "organizational structure that standardizes the project-related governance processes and facilitates the sharing of resources, methodologies, tools, and techniques“ (PMI, 2013, p. 580). Hence, the PMO level is an intermediate organizational structure that is gaining prominence in the project-based environment, due to the need of aligning projects, programs and portfolios with the strategic objectives at the corporate level (Artto et al., 2011; Aubry et al., 2013; Aubry et al., 2011). Moreover, PMOs aim to build, develop and continuously improve project management capabilities and thus increase the maturity of project management in general (Aubry et al., 2011). This further involves tracking and evaluating projects, and allocating and prioritising resources to ensure that "organizational capabilities and competencies are developed to enable projects, programs and portfolios to thrive" (Turner et al., 2010, p. 112).

In PBOs, projects should not be regarded as a series of isolated tasks, but rather as embedded in a mutual, resource dependent system of multiple projects with more or less enduring social relationships (Engwall, 2003; Eskerod, 1996). Projects are never fully self- 
contained, and it is therefore crucial to acquire and prioritize resources, such as money, staff or specific assets, across different-yet interdependent—projects. Often, there are imbalances in the distribution of resources as well as interdependencies among projects within a $\mathrm{PBO}$, which makes project governance complex (Jensen et al., 2006). Resource dependence theory (Pfeffer and Salancik, 1978; Thompson, 2011) may offer project governance researchers valuable tools with which to analyze the allocation, prioritization and facilitation of organizational resources (Oliver, 1991). One of the main problems for projects is how to manage complexity and deliver projects successfully (Thompson, 2011). In other words, "without a governance structure, an organization runs the risk of conflicts and inconsistencies between various means of achieving organizational goals, the processes and resources, thereby causing costly inefficiencies that impact negatively on both smooth running and bottom line profitability" (Müller, 2009, p. 2). A solid governance structure, following the logic of resource dependence theory, can help organizations in act strategically in their environment, manage their projects and buffer external and internal influences, when choosing between different interactive strategies to manage projects in a complex environment (Jensen et al., 2006). These strategies are applicable to both permanent and temporary organizations, and apply across different organizational levels (Jensen et al., 2006).

\subsection{Level of parent organization (corporate governance)}

At the level of the parent organization, the highest project-relevant level, project governance has been described as corporate governance for project based organizations (PBOs) that "defines the objectives of the company, and initiates project, program and portfolio management as the means of obtaining corporate objectives and monitoring progress" (Turner et al., 2010, p. 112). Performance and performance objectives are of a strategic nature, and primarily concerned with long-term effects and the PBO's competitiveness, including its impact on society, benefits for external stakeholders or shareholders, and the sustainability of the projects that it undertakes (Williams and Samset, 2012). At this level, project governance 
is generally concerned with collecting timely, relevant and reliable reports about project portfolios, in order to provide senior management and board executives with information that will support their decision-making processes on a higher PBO level —as an "efficient reporting process will minimize the reporting burden throughout the organization without compromising effectiveness" (APM, 2012, p. 11).

We argue that stakeholder theory and stewardship theory are well suited to conceptualize project governance and its characteristics at this higher organizational level (i.e., long-term orientation and strategic performance). Stakeholder theory evolved around the assumption that organizations have responsibilities towards external and internal stakeholder groups. Stakeholders are any "identifiable group or individual who can affect the achievement of an organization's objectives, or who is affected by the achievement of an organization's objectives" (Freeman and Reed, 1983, p. 91). Stakeholder theory allows researchers to use a relational approach to project governance, which aims to explain how organizations can prioritize and manage relations with identified stakeholders (Mason et al., 2007). Issues around organizational well-being, organizational ethics, sustainability and corporate social responsibility are, therefore, major concerns of the stakeholder theory of project governance. Due to the nature and set-up of many project-based organizations, this type of governance is typically found at higher PBO levels (e.g., corporate level and project management office (PMO) level), where managers deal directly with a broad set of stakeholders (Blomquist and Müller, 2006).

Stewardship theory is also aligned with the objectives of a higher PBO level. The stewardship theory of project governance stands in contrast to the view of agency theory in that it transcends the rational, self-interested and economic interpretation of relationships within an organization (Davis et al., 1997). In other words, stewardship theory of project governance assumes that project managers (or stewards) act in the best interest of the PBO 
and the project sponsor (Davis et al., 1997). The underlying motives of delivering successful projects, therefore, include trust, identification with the particular project, its outcome/s, and the general culture of the PBO. In the project management literature, the concept of stewards

(e.g., project managers and program managers) has been used to describe organizational actors that act in the best interest of principals (e.g. board members and the project sponsor), in order to progress the strategic goals of the PBO and its stakeholders (Turner and Keegan, 2001). In line with the multi-level nature of project governance in PBOs, this view portrays a higher-level form of governance, in which trust, mutual benefits and strategic objectives are the main drivers of governance. In other words, "there must be a culture of trust between the principal (or primary stakeholder) and managers to support this approach" (Mason et al., 2007, p. 290). Stewardship theory of project governance suggests that project sponsors and owners trust and empower project (or program/portfolio) managers, to act in the best interest of the PBO and deliver successful projects.

\section{Conclusion and future research}

The growing number of project governance-related papers indicates that project governance is an increasingly important topic (Figure 1). Thus, the aim of this paper is to provide a systematic review of project governance in major management and project management journals, and to investigate how concepts and themes of dominant corporate governance theories have been applied to the context of project based organizations (PBOs) as multi-level structures. We find that there are a number of specific themes and concepts that suggest the application of corporate governance theories to the project context, such as 'cost' (i.e., transaction cost economics (TCE)), 'trust' (i.e., stewardship theory) or 'control' (i.e., principal agency theory). Other concepts, such as 'strategic', 'contracts' or 'roles', are in line with the general aim of project governance, which is to align project objectives with the strategy of the 
larger organization, via the project sponsor and project team, and through organizational structures and mechanisms. However, our analysis fails to reveal specific governance-related roles, such as shareholder, principal, agent, project sponsor or owner, or steward.

In line with existing research on project governance (Bredillet, 2008b; Söderlund, 2011), we further find that the main empirical context of project governance is construction (e.g., Turner and Keegan, 2001; Winch, 2001). We therefore suggest that additional research contexts are needed to progress project governance research. To enhance our understanding of project governance, it would be particularly interesting to include contexts in which projects are more transient, more agile and, therefore, less driven by structured approaches. A focus on information technology companies, particularly in the area of software development, will certainly help to further validate the concept of project governance-since project governance is always subject to context-specific requirements (O'Leary and Williams, 2012).

Furthermore, in line with the Governance School of project management (Bredillet, 2007; Söderlund, 2004) our findings highlight three particular areas of previous research interest: (i) transaction costs associated with projects; (ii) the principal agency relationship between client and contractor, and (iii) general mechanisms of governance of projects (Bredillet, 2008a). Much previous research applied either agency theory or TCE concepts and themes (such as cost, relationships and mechanisms) to investigate "the overall and contractual aspects, the choice of project contracts and the forms of bilateral or trilateral governance to handle large-scale projects" (Söderlund, 2011, p. 163).

We suggest that additional governance theories are also suited to explain project governance at various project levels. Project governance is a multi-level phenomenon at the intersection of projects, programs and portfolio management levels, which aids the successful achievement of organizational and project objectives (Müller, 2009). It is thus defined by the duality of successfully meeting objectives, set out by particular projects, but also by 
acknowledging overarching organizational objectives. Stressing the effects of effective project governance, (Weaver, 2005) argues that project governance contributes to a firm's performance as it helps to manage and minimize project risk, improve transparency between different organizational levels (in order to meet project objectives), and positively influences the exchange of relevant information across different stakeholder groups (Müller, 2009).

However, this research is subject to limitations. One is that some influential research in the field of project governance may have been published in books (such as the Oxford Handbook of Project Management) and conference proceedings, which were not included in the data. Further, our analysis only included papers that used the identifier 'project governance' (wider management, engineering and IT journals) and 'governance' (project management journals) in their titles, keywords and/or abstracts. This effectively omits research on closely related constructs or constructs that underlie governance research in particular, such as the terms 'stakeholder theory', 'shareholder value' and 'transaction cost economics'. Furthermore, our searches did not include keywords that may be a clear indication of central governance theories, such as the terms 'principal' and 'transaction costs'. While using these keywords to create the dataset of articles published in project management journals, the same search would have returned many unrelated articles in the general management, IT and engineering journals search. However, the focus of our study was to analyze how project governance was specifically used in previously published research, and papers that did not explicitly use the term '(project) governance' may not intend to be associated with this research field. Therefore, at this stage, it is important to acknowledge and refer to the rich, project-based governance literature, from which the concept of project governance originated in the mid-twentieth century (e.g., Clegg et al., 2002; Eccles, 1981; Morris, 1997; Stinchcombe, 1959). 
Future empirical research should focus on investigating project governance with respect to different suggested organizational levels. Level-specific research offers the ability to draw context-specific conclusions and explain actions and practices, with regards to the roles and responsibilities of particular organizational layers Here, existing governance theories play a vital role, as they offer valuable starting points for level-specific understandings of project governance. As Hällgren (2012) outlines, project management research is overly concerned with gap spotting and the creation of new project management theories. Instead, we argue that we should explore the value of existing theories that represent a multi-perspective, cross-functional picture of project governance, in regards to the multilevel nature or projects and PBOs. This would enable the field of project management to overcome over-specialization and fragmentation, and draw from a well-established theoretical corpus while remaining open to innovative and constructive ideas (Söderlund, 2011). In other words, project governance research should be seen as an extension of corporate governance theories, that can draw on a substantial body of existing theories, to create context-specific theories of governance in a project context while challenging basic assumptions of the research process.

From a practical perspective, project governance ensures that a project is executed according to the standards of a particular PBO and its institution. Project governance, therefore, creates transparency across all project activities and across different organizational layers, which in turn creates accountabilities. More specifically, project governance often installs a project reporting system that specifically outlines roles and responsibilities for all stakeholders involved in the project. A good governance structure does not restrain the ability of project managers to act flexibly and accommodate for unexpected changes, rather, it helps project manages set project priorities. 
Understanding the particular governance of a PBO and its larger objectives enables project managers to identify which objectives to pursue and prioritize in order to deliver a successful project. Certain objectives can be changes or amended that are misaligned with the overall strategic objectives of the PBO. A good governance structure further ensures that each individual project remains in alignment with the greater organizational goal of the PBO. Moreover, higher organizational boards (e.g., steering committees), which are often an essential part of organizational governance structure, can be used in a support function in order to solve problems or ambiguities, or adhere to institutional standards, without losing sight of greater strategic objectives. Hence, we can conclude that project governance is an important and useful aspect of delivering successful projects, which goes beyond pure organizational control and planning, and therefore, it should be used as an enabler of collaboration and reflection. 


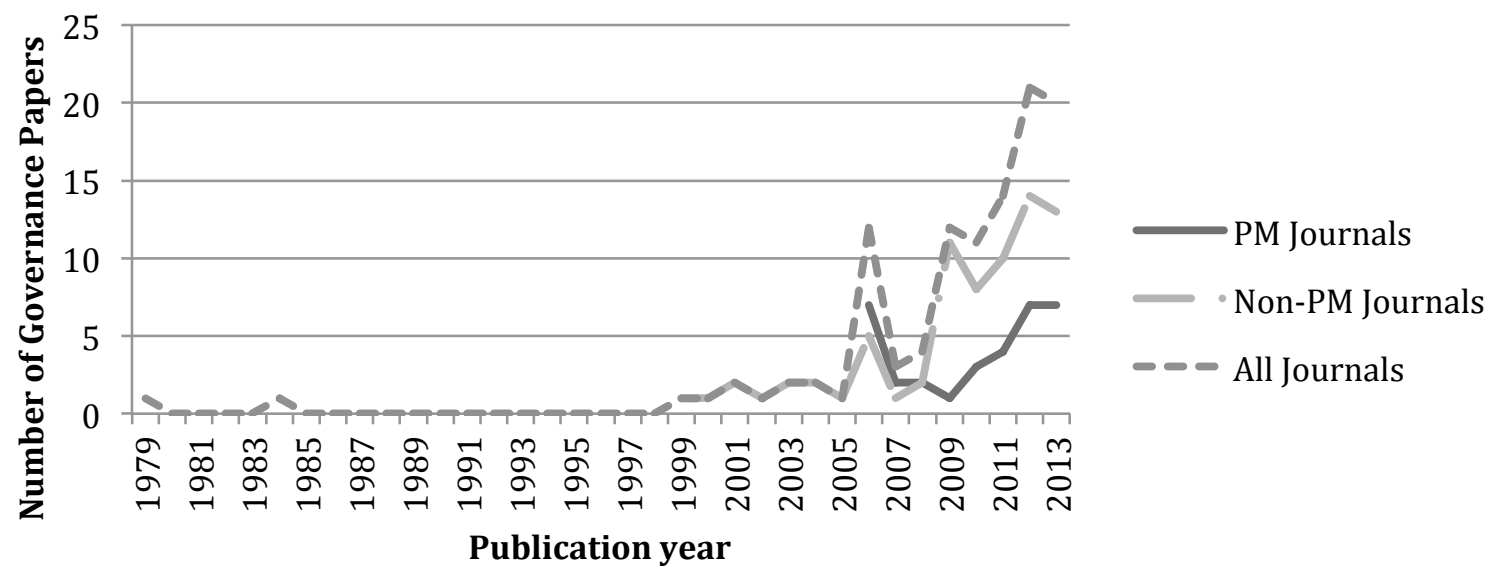

Figure 1: Number of Journal papers on Project Governance over the years (based on Scopus search) 


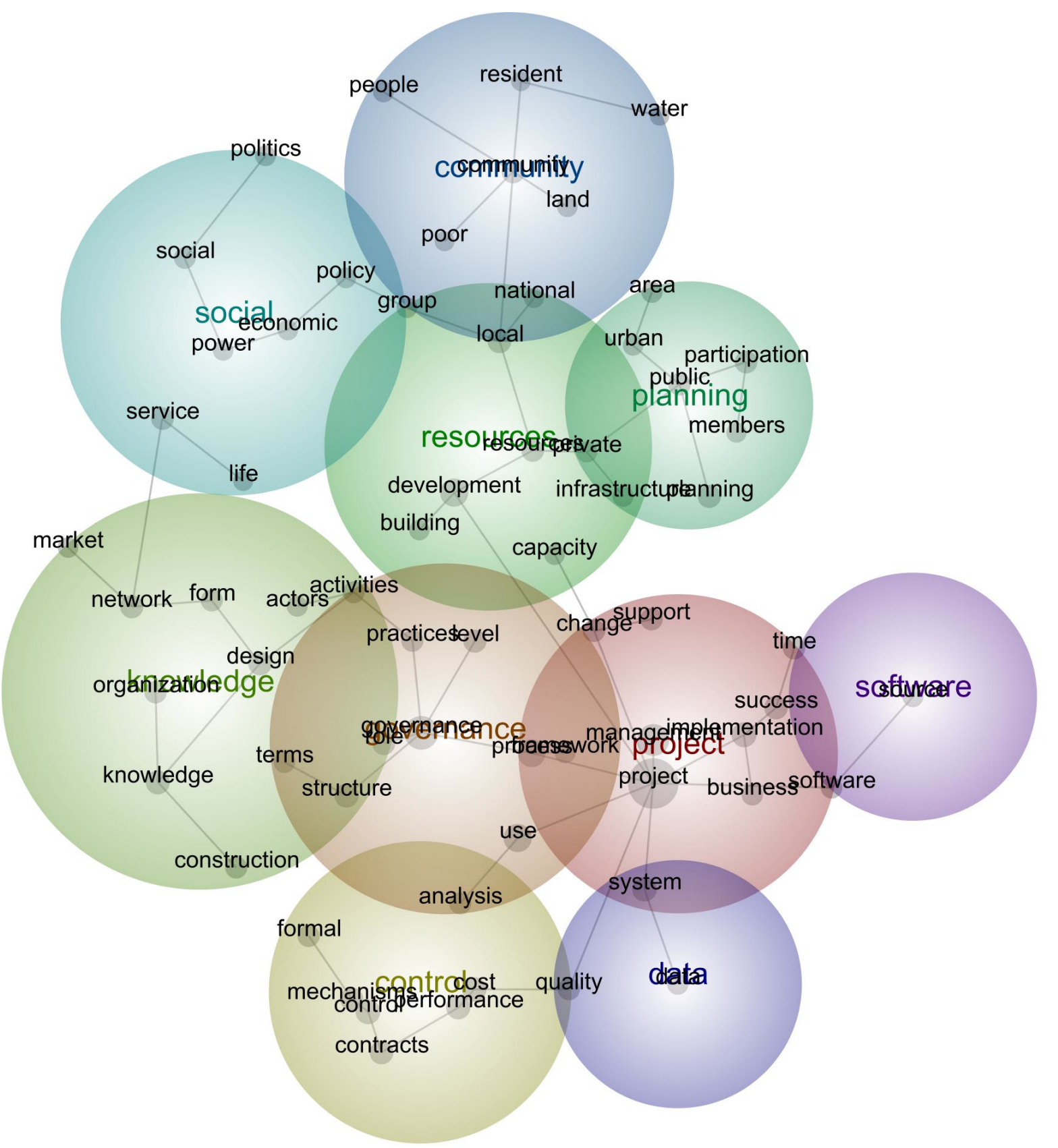

Figure 2: A corpus of texts on governance in management and organization literature 


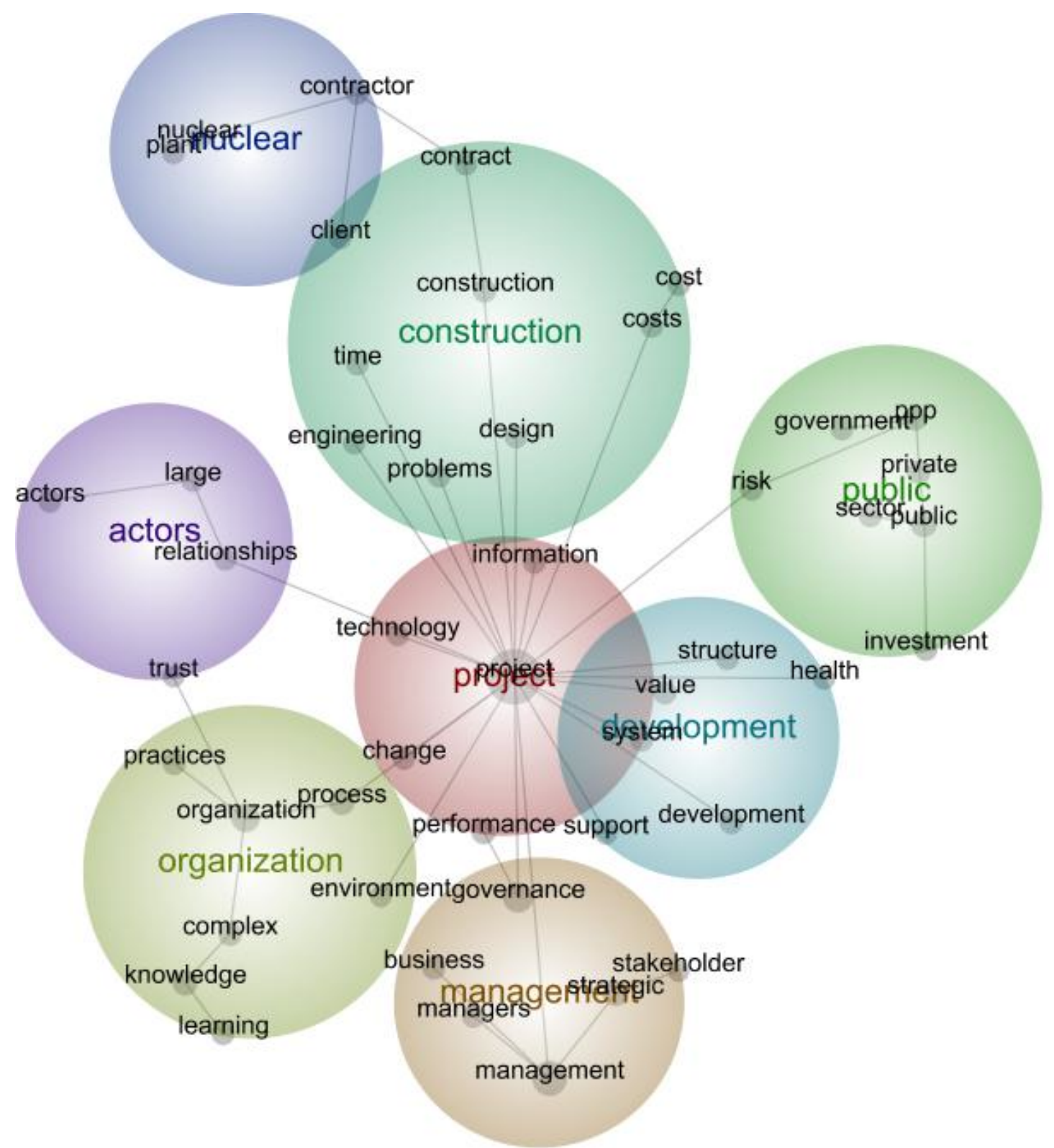

Figure 3: The specialized corpus of project management literature that deals with governance 
Table 1: Summary of central governance theories

\begin{tabular}{|c|c|c|}
\hline Theory & Summary & Key authors \\
\hline $\begin{array}{l}\text { Agency } \\
\text { Theory }\end{array}$ & $\begin{array}{l}\text { Agency theory identifies an agency relationship of two parties (the } \\
\text { principal and the agent) in organizations. Both actors are perceived as } \\
\text { rational economic actors that act in a self-interested manner. The } \\
\text { governance structure is cost and control oriented and may favor } \\
\text { short-term results. }\end{array}$ & $\begin{array}{l}\text { Mitnick (1973), Ross } \\
\text { (1973) }\end{array}$ \\
\hline $\begin{array}{l}\text { Transaction } \\
\text { cost } \\
\text { economics }\end{array}$ & $\begin{array}{l}\text { Transaction cost economics (TCE) implies that organizations adapt } \\
\text { their governance structures to achieve the lowest possible transaction } \\
\text { costs. However, TCE assumes a complex relationship between buyer } \\
\text { and seller. Behavioral factors are also considered when choosing a } \\
\text { particular transaction. }\end{array}$ & $\begin{array}{l}\text { Williamson (1975), } \\
\text { Coase (1973) }\end{array}$ \\
\hline $\begin{array}{l}\text { Stakeholder } \\
\text { theory }\end{array}$ & $\begin{array}{l}\text { Stakeholder theory takes into account of a wider group of } \\
\text { constituents rather than focusing on shareholders. Where there is an } \\
\text { emphasis on stakeholders, the governance structure of the company } \\
\text { may provide for some direct representation of the stakeholder groups. }\end{array}$ & $\begin{array}{l}\text { Donaldson (1995), } \\
\text { Freeman (1984) }\end{array}$ \\
\hline $\begin{array}{l}\text { Shareholder } \\
\text { theory }\end{array}$ & $\begin{array}{l}\text { The Shareholder theory of corporate governance assumes that the } \\
\text { main purpose of an organization is to maximize shareholder return on } \\
\text { investment (ROI). This requires structures (such as contracts, } \\
\text { processes and policies) to assure managerial action is always in the } \\
\text { best interests of the shareholders. }\end{array}$ & $\begin{array}{l}\text { Jensen and Meckling } \\
(1976), \text { Friedman (1962) }\end{array}$ \\
\hline $\begin{array}{l}\text { Stewardship } \\
\text { theory }\end{array}$ & $\begin{array}{l}\text { Stewardship theory defines a relationship between organizational } \\
\text { actors, in which the managers are not motivated by individual goals, } \\
\text { but rather are stewards whose motives are aligned with the objectives } \\
\text { of their principals. The governance structure is built on trust to } \\
\text { enhance the long-term performance of the organization. }\end{array}$ & $\begin{array}{l}\text { Donaldson (1990), } \\
\text { Davis et al. (1997) }\end{array}$ \\
\hline $\begin{array}{l}\text { Resource } \\
\text { dependence } \\
\text { theory }\end{array}$ & $\begin{array}{l}\text { Directors are able to prioritize, acquire, facilitate and connect the } \\
\text { company's internal and external resources needed to achieve } \\
\text { corporate objectives. }\end{array}$ & $\begin{array}{l}\text { Pfeffer and Salancik } \\
(1978)\end{array}$ \\
\hline
\end{tabular}


Table 2: Summary of key project governance definitions

\begin{tabular}{ll}
\hline Author & Definition \\
\hline Turner $(2009$, p. 311) & $\begin{array}{l}\text { The governance of a project involves a set of relationships between the } \\
\text { project's management, its sponsor (or executive board), its owner and } \\
\text { other stakeholders. It provides the structure through which the objectives } \\
\text { of the project are set, and the means of attaining those objectives and } \\
\text { monitoring performance are determined. }\end{array}$ \\
The alignment of project objectives with the strategy of the larger \\
organization by the project sponsor and project team. A project's \\
governance is defined by and is required to fit within the larger context of \\
the program or organization sponsoring it, but is separate from \\
organizational governance. \\
Governance, as it applies to portfolios, programs, projects, and project \\
management, coexists within the corporate governance framework. It \\
comprises the value system, responsibilities, processes and policies that \\
allow projects to achieve organizational objectives and foster \\
implementation that is in the best interests of all the stakeholders, internal \\
and external, and the corporation itself.
\end{tabular}


Table 3: Overview of Papers in Project Management Journals

\begin{tabular}{|c|c|c|c|c|}
\hline Authors & Title & Year & Journal & Summary \\
\hline Too E.G., Weaver P. & $\begin{array}{l}\text { The management of project } \\
\text { management: A conceptual framework } \\
\text { for project governance }\end{array}$ & 2013 & IJPM & $\begin{array}{l}\text { This paper examines existing research, ideas and concepts of project } \\
\text { governance and enterprise project management, and offers a framework } \\
\text { to build on current theory development and practice. The purpose of the } \\
\text { framework described in this paper is to provide guidance to organizations } \\
\text { in the development of effective project governance to optimize the } \\
\text { management of projects. }\end{array}$ \\
\hline $\begin{array}{l}\text { Aubry M., Richer M.-C., Lavoie- } \\
\text { Tremblay M. }\end{array}$ & $\begin{array}{l}\text { Governance performance in complex } \\
\text { environment: The case of a major } \\
\text { transformation in a university hospital }\end{array}$ & 2013 & IJPM & $\begin{array}{l}\text { Project-based organizations have emerged as new forms of organization } \\
\text { in the last few decades. However, hierarchy persists. Both serve their own } \\
\text { purpose, but entail different sets of values. Findings reveal the existence } \\
\text { of paradoxes between the executives and the PMO regarding the PMO } \\
\text { performance and show how these paradoxes evolved over time. }\end{array}$ \\
\hline $\begin{array}{l}\text { Muller R., Andersen E.S., Kvalnes O., } \\
\text { Shao J., Sankaran S., Rodney Turner } \\
\text { J., Biesenthal C., Walker D., Gudergan } \\
\text { S. }\end{array}$ & $\begin{array}{l}\text { The interrelationship of governance, } \\
\text { trust, and ethics in temporary } \\
\text { organizations }\end{array}$ & 2013 & PMJ & $\begin{array}{l}\text { This study investigates the variety of ethical decisions of project } \\
\text { managers and their impact from corporate governance and project } \\
\text { governance structures. The roles of personal trust and system trust as a } \\
\text { mechanism to steer ethical decision making in different governance } \\
\text { settings is explored. }\end{array}$ \\
\hline Ahern T., Leavy B., Byrne P.J. & $\begin{array}{llcr}\text { Complex } & \text { project } & \text { management } & \text { as } \\
\text { complex } & \text { problem } & \text { solving: A } \\
\text { distributed } & \text { knowledge } & \text { management } \\
\text { perspective } & & & \end{array}$ & 2013 & IJPM & $\begin{array}{l}\text { Central to the view of complex project management as a form of complex } \\
\text { problem solving is the governance challenge of knowledge management } \\
\text { under uncertainty. This paper proposes that the distributed coordination } \\
\text { mechanism which both organizations evolved for this contingency can } \\
\text { best be characterized as a 'common will of mutual interest', a self- } \\
\text { organizing process that was fostered around project goals and paced by } \\
\text { the project life cycle. }\end{array}$ \\
\hline $\begin{array}{l}\text { Hellstrom M., Ruuska I., Wikstrom K., } \\
\text { Jafs D. }\end{array}$ & $\begin{array}{l}\text { Project governance and path creation in } \\
\text { the early stages of Finnish nuclear } \\
\text { power projects }\end{array}$ & 2013 & IJPM & $\begin{array}{l}\text { This paper focuses on the early stages of projects and their governance } \\
\text { implications by investigating the introduction of nuclear power in } \\
\text { Finland. The paper argues that strong relationships and commitment } \\
\text { create opportunities for alternative paths during project appraisal, } \\
\text { increase the array of available governance mechanisms, and hence lay } \\
\text { foundations for the final governance structure of the project execution } \\
\text { phase. }\end{array}$ \\
\hline
\end{tabular}




\begin{tabular}{|c|c|c|c|c|}
\hline Pinto J.K. & $\begin{array}{l}\text { Project management, governance, and } \\
\text { the normalization of deviance }\end{array}$ & 2013 & IJPM & $\begin{array}{l}\text { Using results from interviews with } 21 \text { project managers, this paper } \\
\text { considers how normalization of deviance affects project management } \\
\text { practices. The paper examines the role of organizational learning and } \\
\text { corporate governance in identifying and minimizing the negative impact } \\
\text { of normalization of deviance behaviors on project-based work. }\end{array}$ \\
\hline Nisar T.M. & $\begin{array}{l}\text { Implementation constraints in social } \\
\text { enterprise and community Public } \\
\text { Private Partnerships }\end{array}$ & 2013 & IJPM & $\begin{array}{l}\text { This paper examines three community Public Private Partnership (PPP) } \\
\text { projects to identify critical success factors of the project outcomes. The } \\
\text { findings suggest the need to implement appropriate project governance } \\
\text { practices including management discipline and expertise. }\end{array}$ \\
\hline Koh A., Crawford L. & $\begin{array}{l}\text { Portfolio management: The Australian } \\
\text { experience }\end{array}$ & 2012 & PMJ & $\begin{array}{l}\text { The increasing use of projects and programs by organizations to achieve } \\
\text { business strategy and goals has led to the need for understanding project } \\
\text { portfolio management. This study investigates the governance structures } \\
\text { and the roles, responsibilities, and practices of portfolio managers. }\end{array}$ \\
\hline Pemsel S., Muller R. & $\begin{array}{l}\text { The governance of knowledge in } \\
\text { project-based organizations }\end{array}$ & 2012 & IJPM & $\begin{array}{l}\text { This research investigates patterns of knowledge governance practices in } \\
\text { project-based organizations (PBOs). The results show that informal } \\
\text { governance mechanisms are more useful than formal when it comes to } \\
\text { knowledge creating processes. Governance of informal knowledge } \\
\text { creating mechanisms appears to be complex for executives and their } \\
\text { preconceptions showed either to be enablers or barriers to productive } \\
\text { knowledge governance practices. }\end{array}$ \\
\hline $\begin{array}{l}\text { Young R., Young M., Jordan E., } \\
\text { O'Connor P. }\end{array}$ & $\begin{array}{l}\text { Is strategy being implemented through } \\
\text { projects? Contrary evidence from a } \\
\text { leader in New Public Management }\end{array}$ & 2012 & IJPM & $\begin{array}{l}\text { This paper reports on the effectiveness of the project management and } \\
\text { investment frameworks in the State of Victoria. It finds project } \\
\text { management and investment practices comparable to best practice but } \\
\text { also finds } 100 \text { billion dollars invested in projects over the past decade } \\
\text { without any evidence of improvement in strategic goals. }\end{array}$ \\
\hline $\begin{array}{l}\text { Tadege Shiferaw A., Jonny Klakegg } \\
\text { O., Haavaldsen T. }\end{array}$ & $\begin{array}{l}\text { Governance of public investment } \\
\text { projects in Ethiopia }\end{array}$ & 2012 & PMJ & $\begin{array}{l}\text { The purpose of this article is to map and review the governance of public } \\
\text { investment projects in Ethiopia and to identify the most important front- } \\
\text { end challenges of public investment projects in the country. The findings } \\
\text { indicate that the top-down project approach, lack of mandatory control } \\
\text { gateways at the front-end project preparation and decision-making stages, } \\
\text { and weak links between project stakeholders, affected the effectiveness of } \\
\text { the project governance system. }\end{array}$ \\
\hline
\end{tabular}




\begin{tabular}{|c|c|c|c|c|}
\hline $\begin{array}{l}\text { Tadege Shiferaw A., Jonny Klakegg } \\
\text { O. }\end{array}$ & $\begin{array}{l}\text { Linking policies to projects: The key to } \\
\text { identifying the right public investment } \\
\text { projects }\end{array}$ & 2012 & PMJ & $\begin{array}{l}\text { This article reviews the merits of project governance in linking policies to } \\
\text { projects and focuses on public investment projects in African countries. It } \\
\text { provides a project governance model to link policies to projects, a } \\
\text { checklist for good project governance, and an outline of factors that could } \\
\text { affect the project governance implementation. }\end{array}$ \\
\hline Sanderson J. & $\begin{array}{l}\text { Risk, uncertainty and governance in } \\
\text { megaprojects: A critical discussion of } \\
\text { alternative explanations }\end{array}$ & 2012 & IJPM & $\begin{array}{l}\text { This article critically discusses different explanations for the performance } \\
\text { problems exhibited by many megaprojects, and examines the proposed } \\
\text { governance solutions. It proposes a three-fold typology of explanations } \\
\text { and solutions by examining epistemological assumptions about decision- } \\
\text { maker cognition and about decision-maker views on the nature of the } \\
\text { future. }\end{array}$ \\
\hline Ritson G., Johansen E., Osborne A. & $\begin{array}{l}\text { Successful programs wanted: } \\
\text { Exploring the impact of alignment }\end{array}$ & 2012 & PMJ & $\begin{array}{l}\text { This paper explores the development of a program management } \\
\text { alignment theory. Statistical testing showed that interaction between the } \\
\text { study model variables was found to be multidimensional, complex, and } \\
\text { subtle in influence. Thus, the paper concludes that programs have both } \\
\text { deliberate and emergent strategies requiring design and management to } \\
\text { be organized as complex adaptive systems. }\end{array}$ \\
\hline $\begin{array}{l}\text { Aubry M., Richer M.-C., Lavoie- } \\
\text { Tremblay M., Cyr G. }\end{array}$ & $\begin{array}{l}\text { Pluralism in PMO performance: The } \\
\text { case of a PMO dedicated to a major } \\
\text { organizational transformation }\end{array}$ & 2011 & PMJ & $\begin{array}{l}\text { The focus of this article is on the contribution made by the project } \\
\text { management office (PMO) to organizational performance, and the way it } \\
\text { can be assessed. The paper particularly explores the case of a PMO } \\
\text { dedicated to a major organizational transformation within a Canadian } \\
\text { university hospital, and show that competing value/performance } \\
\text { frameworks exist. }\end{array}$ \\
\hline London K., Siva J.P.S. & $\begin{array}{l}\text { The role of reflexive capability in } \\
\text { relation to intellectual capital on multi } \\
\text { international partnerships }\end{array}$ & 2011 & IJPM & $\begin{array}{l}\text { This paper analysis firms' barriers and successful strategies in decision } \\
\text { making in various international markets. A reflexive capability model } \\
\text { developed from social sciences theory explains the way in which firms } \\
\text { can develop awareness, responsiveness and adaptability for long-term } \\
\text { success in diverse international markets. Results indicate that the model } \\
\text { of reflexivity capability is a useful way to interpret practices that are } \\
\text { undertaken in multi-partner relationships on large complex projects. }\end{array}$ \\
\hline
\end{tabular}




\begin{tabular}{|c|c|c|c|c|}
\hline Marnewick C., Labuschagne L. & $\begin{array}{l}\text { An investigation into the governance of } \\
\text { information technology projects in } \\
\text { South Africa }\end{array}$ & 2011 & IJPM & $\begin{array}{l}\text { Information technology (IT) projects are often perceived as adding little } \\
\text { or no organizational value despite substantial investments being made. } \\
\text { The non-adoption of governance principles might contribute to this } \\
\text { perception as unfeasible projects are often approved and initiated without } \\
\text { proper discourse. This article reports on the investigation of IT projects in } \\
\text { South African organizations to determine whether generally accepted } \\
\text { governance principles were applied in the project domain. }\end{array}$ \\
\hline $\begin{array}{l}\text { Ruuska I., Ahola T., Artto K., } \\
\text { Locatelli G., Mancini M. }\end{array}$ & $\begin{array}{l}\text { A new governance approach for multi- } \\
\text { firm projects: Lessons from Olkiluoto } 3 \\
\text { and Flamanville } 3 \text { nuclear power plant } \\
\text { projects }\end{array}$ & 2011 & IJPM & $\begin{array}{l}\text { We suggest that in the governance of large multi-firm projects, any of the } \\
\text { prevalent governance approaches that rely on market, hierarchy, or hybrid } \\
\text { forms, is not adequate as such. By doing so, this paper opens up avenues } \\
\text { towards a novel theory of governance in large projects by adopting a } \\
\text { project network view with multiple networked firms within a single } \\
\text { project, and by simultaneously going beyond organizational forms that } \\
\text { cut across the traditional firm-market dichotomy. }\end{array}$ \\
\hline Bouraad F. & $\begin{array}{l}\text { IT project portfolio governance: The } \\
\text { emerging operation manager }\end{array}$ & 2010 & PMJ & $\begin{array}{l}\text { This article presents a detailed analysis of available IT operations } \\
\text { literature in order to identify the most appropriate competencies and } \\
\text { necessary skill sets that will be needed by an operation manager for } \\
\text { strategic business alignment. }\end{array}$ \\
\hline Jonas D. & $\begin{array}{l}\text { Empowering project portfolio } \\
\text { managers: How management } \\
\text { involvement impacts project portfolio } \\
\text { management performance }\end{array}$ & 2010 & IJPM & $\begin{array}{l}\text { Along with the increasing diffusion of project portfolio management a } \\
\text { new managerial role evolves: the project portfolio manager. This paper } \\
\text { investigates the role of the project portfolio manager and its interplay } \\
\text { with line and senior management to explain how management } \\
\text { involvement can positively and negatively impact project portfolio } \\
\text { success at the same time. }\end{array}$ \\
\hline $\begin{array}{l}\text { Williams T., Klakegg O.J., Magnussen } \\
\text { O.M., Glasspool H. }\end{array}$ & $\begin{array}{l}\text { An investigation of governance } \\
\text { frameworks for public projects in } \\
\text { Norway and the UK }\end{array}$ & 2010 & IJPM & $\begin{array}{l}\text { This paper describes four case studies which formed a key part of an } \\
\text { investigation into public investment project governance frameworks in } \\
\text { Norway and the UK. The studies looked at how the embedded } \\
\text { governance principles worked out in practice, how they affected PM, and } \\
\text { how consistent their effects were with their aims. Conclusion is made } \\
\text { about the actual effects of the frameworks, and various areas for } \\
\text { improvement or further study are highlighted. }\end{array}$ \\
\hline
\end{tabular}




\begin{tabular}{|c|c|c|c|c|}
\hline $\begin{array}{l}\text { Ruuska I., Artto K., Aaltonen K., } \\
\text { Lehtonen P. }\end{array}$ & $\begin{array}{l}\text { Dimensions of distance in a project } \\
\text { network: Exploring Olkiluoto } 3 \text { nuclear } \\
\text { power plant project }\end{array}$ & 2009 & IJPM & $\begin{array}{l}\text { This paper proposes that many of the challenges of implementing large } \\
\text { multi-firm projects are captured in the multi-dimensional concept of } \\
\text { distance between firms in a large project's actor network. By addressing } \\
\text { projects as multi-firm enterprises with specific distance characteristics, } \\
\text { our research opens up a path towards novel management of a project that } \\
\text { engages several firms in its sphere of governance. }\end{array}$ \\
\hline Bredillet C.N. & $\begin{array}{l}\text { Learning and acting in project } \\
\text { situations through a meta-method } \\
\text { (MAP) a case study: Contextual and } \\
\text { situational approach for project } \\
\text { management governance in } \\
\text { management education }\end{array}$ & 2008 & IJPM & $\begin{array}{l}\text { The paper introduces the underlying principles and the general features of } \\
\text { a meta-method (MAP method) developed as part of and used in various } \\
\text { research, education and professional development programs at ESC Lille. } \\
\text { This method aims at providing effective and efficient structure and } \\
\text { process for acting and learning in various complex, uncertain and } \\
\text { ambiguous managerial situations (projects, programs, portfolios). }\end{array}$ \\
\hline Wearne S. & $\begin{array}{l}\text { Stakeholders in excellence in teaching } \\
\text { and learning of project management }\end{array}$ & 2008 & IJPM & $\begin{array}{l}\text { The paper reports differences in how post-graduate and experienced } \\
\text { 'students', their employers and others appear to value and therefore may } \\
\text { judge the excellence of teaching of project management. Stakeholders } \\
\text { can see excellence from unexpected value obtained from courses. The } \\
\text { teachers and all concerned when promoting and selecting teaching of } \\
\text { project management should therefore consider together what should be } \\
\text { expected and what could be obtained from what they think is needed and } \\
\text { what can be provided. }\end{array}$ \\
\hline Thiry M., Deguire M. & $\begin{array}{l}\text { Recent developments in project-based } \\
\text { organisations }\end{array}$ & 2007 & IJPM & $\begin{array}{l}\text { Project-based organizations (PBO) refer to a variety of organizational } \\
\text { forms that involve the creation of temporary systems for the performance } \\
\text { of project tasks. This paper argues that an important aspect of PBOs is } \\
\text { yet unexplored and lies in the development of a collaborative relationship } \\
\text { between the fields of project and general management and the importance } \\
\text { of developing a common language that fosters dialogue. }\end{array}$ \\
\hline Chang C.-Y., Ive G. & $\begin{array}{l}\text { The hold-up problem in the } \\
\text { management of construction projects: } \\
\text { A case study of the Channel Tunnel }\end{array}$ & 2007 & IJPM & $\begin{array}{l}\text { The hold-up problem in the presence of asset specificity poses great } \\
\text { transaction hazards. Therefore, having a sound understanding of this } \\
\text { problem is an important managerial issue. The purpose of this research is } \\
\text { to apply the perspective of transaction cost economics (TCE) to the } \\
\text { analysis of three major disputes that arose in the Channel Tunnel project } \\
\text { during 1988-94. }\end{array}$ \\
\hline
\end{tabular}




\begin{tabular}{|c|c|c|c|c|}
\hline Devapriya K.A.K. & $\begin{array}{l}\text { Governance issues in financing of } \\
\text { public-private partnership organisations } \\
\text { in network infrastructure industries }\end{array}$ & 2006 & IJPM & $\begin{array}{l}\text { Public-private partnership (PPP) organizational approaches to generation, } \\
\text { management and operation of network infrastructure and services have } \\
\text { widely followed competitive market forms under different regulatory } \\
\text { regimes. Managerial decisions on financing of PPP companies have been } \\
\text { governed by regulatory markets with unstable institutions in developing } \\
\text { and emerging economies. This paper reveals that debt has not been an } \\
\text { effective mechanism to control managers' behavior since subordinate } \\
\text { financing also functions to address debt agency in the capital structure of } \\
\text { those regulated PPP organizations. }\end{array}$ \\
\hline Abednego M.P., Ogunlana S.O. & $\begin{array}{l}\text { Good project governance for proper } \\
\text { risk allocation in public-private } \\
\text { partnerships in Indonesia }\end{array}$ & 2006 & IJPM & $\begin{array}{l}\text { Parties that are involved in an infrastructure project under public-private } \\
\text { partnership (PPP) procurement system typically have different } \\
\text { perceptions of proper risk allocation. This research is conducted to } \\
\text { discover the perception of proper risk allocation of each party involved } \\
\text { and utilizes the findings as the foundation to develop the concept of good } \\
\text { project governance. }\end{array}$ \\
\hline Clifton C., Duffield C.F. & $\begin{array}{l}\text { Improved PFI/PPP service outcomes } \\
\text { through the integration of Alliance } \\
\text { principles }\end{array}$ & 2006 & IJPM & $\begin{array}{l}\text { This paper explores management and governance of private finance } \\
\text { initiatives/public private partnership (PFI/PPP) projects via the } \\
\text { integration of Alliance concepts into the typical concession agreements. } \\
\text { In this context, appropriate governance is defined as achieving and } \\
\text { improving long-term service outcomes. This paper presents the findings } \\
\text { of a study that has investigated aspects of contract structure, risk } \\
\text { management and those features of concession agreements that drive } \\
\text { service behavior. }\end{array}$ \\
\hline Jerzy Henisz W.(V.) & $\begin{array}{l}\text { Governance issues in public private } \\
\text { partnerships }\end{array}$ & 2006 & IJPM & $\begin{array}{l}\text { Academic research has increasingly shifted from debating the relative } \\
\text { efficacy of state- and private-ownership to a comparative institutional } \\
\text { approach that seeks to identify the relative costs and competencies of } \\
\text { these governance forms to deal with particular hazards in specific } \\
\text { transactions. Recent research, including the } 10 \text { articles included in this } \\
\text { special issue, expands upon this insight to explore not only the polar } \\
\text { cases of state- and private-ownership but also hybrid or alliance forms of } \\
\text { governance. }\end{array}$ \\
\hline
\end{tabular}




\begin{tabular}{|c|c|c|c|c|}
\hline Fischer K., Jungbecker A., Alfen H.W. & $\begin{array}{l}\text { The emergence of PPP Task Forces and } \\
\text { their influence on project delivery in } \\
\text { Germany }\end{array}$ & 2006 & IJPM & $\begin{array}{l}\text { The paper aims at revealing why institutions like public-private } \\
\text { partnership (PPP) Task Forces have an impact on the realization of PPP } \\
\text { projects and the achievement of Value for Money in PPPs. The paper } \\
\text { highlights the impact of Task Forces on the implementation of PPP } \\
\text { projects in Germany and features their influence on the procurement } \\
\text { process and the achievement of Value for Money. }\end{array}$ \\
\hline Holmes J., Capper G., Hudson G. & $\begin{array}{l}\text { Public Private Partnerships in the } \\
\text { provision of health care premises in the } \\
\text { UK }\end{array}$ & 2006 & IJPM & $\begin{array}{l}\text { This paper presents a study of the Local Improvement Finance Trusts } \\
\text { (LIFTs) that are being used to procure new health care premises } \\
\text { throughout the UK. In terms of governance, the procurement process was } \\
\text { extended to later phases before full evaluations of the schemes had been } \\
\text { undertaken. Findings further show the additional cost of premises } \\
\text { procured in the above manner and the ability of the scheme to meet the } \\
\text { government's objectives in the later phases. }\end{array}$ \\
\hline Turner J.R. & $\begin{array}{l}\text { Towards a theory of project } \\
\text { management: The nature of the project } \\
\text { governance and project management }\end{array}$ & 2006 & IJPM & $\begin{array}{l}\text { In multiple editorials, Turner develops a theory of project management. } \\
\text { Through a series of premises and dilemmas he attempts to derive a } \\
\text { structure of project management, and identify inherent elements of } \\
\text { project management. In that last issue, I looked at the nature of projects } \\
\text { and identified two premises and five lemmas, eight inherent elements of } \\
\text { project management and four roles, including the role of governance in } \\
\text { projects. }\end{array}$ \\
\hline Reve T., Levitt R.E. & $\begin{array}{l}\text { Organization and governance in } \\
\text { construction }\end{array}$ & 1984 & IJPM & $\begin{array}{l}\text { Transaction cost analysis provides a viable theoretical perspective for the } \\
\text { study of organization and governance in construction. The trilateral } \\
\text { governance of a client, engineering consultant, and contractors commonly } \\
\text { observed in industrial construction projects is detailed. The implications } \\
\text { of a professional relationship between the client and the consultant and a } \\
\text { clan-type relationship between the consultant and the contractors are } \\
\text { discussed within the context of large construction projects. }\end{array}$ \\
\hline
\end{tabular}


Table 4: Overview of different levels of project governance and proposed theories

\begin{tabular}{|c|c|c|c|}
\hline Governance ... & Project level & PMO level & Organizational level \\
\hline ... Objectives & $\begin{array}{l}\text { Governance of individual } \\
\text { project }\end{array}$ & $\begin{array}{l}\text { Linking projects to } \\
\text { organizational objectives }\end{array}$ & $\begin{array}{l}\text { Governance of Project } \\
\text { Management (GoPM) }\end{array}$ \\
\hline $\begin{array}{l}\text {...Task } \\
\text { (Accountabilities) }\end{array}$ & $\begin{array}{ll}\text { - } & \text { Project management } \\
\text { - } & \text { Project delivery } \\
\text { Manage objectives, } \\
\text { expectations and } \\
\text { outcomes }\end{array}$ & 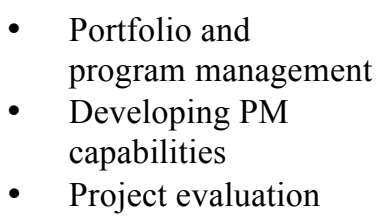 & $\begin{array}{ll}\text { - } & \text { Portfolio direction } \\
\text { - } & \text { Project sponsorship } \\
\text { - } & \text { Disclosure and reporting }\end{array}$ \\
\hline Performance & $\begin{array}{ll}\text { - } & \text { Tactical } \\
\text { - } & \text { Short-term } \\
& \text { (temporary) } \\
\text { - } & \text { Goal directed }\end{array}$ & $\begin{array}{ll}\text { - } & \text { Operational } \\
\text { - } & \text { Long- and short-term } \\
\text { Organizational } \\
\text { development and } \\
\text { progress }\end{array}$ & $\begin{array}{ll}\text { - } & \text { Strategic } \\
\text { - } & \text { Long-term (permanent) } \\
\text { - } & \text { Competitive advantage }\end{array}$ \\
\hline $\begin{array}{l}\text { Governance } \\
\text { Theories }\end{array}$ & $\begin{array}{l}\text { - } \\
\text { - } \quad \text { Transaction Cost } \\
\text { Economics }\end{array}$ & $\begin{array}{l}\text { - Resource } \\
\text { Dependency Theory }\end{array}$ & $\begin{array}{l}\text { - Stewardship Theory } \\
\text { - } \quad \text { Stakeholder Theory }\end{array}$ \\
\hline
\end{tabular}




\section{References}

Aaltonen, K., Sivonen, R., 2009. Response strategies to stakeholder pressures in global projects. International Journal of Project Management, 27, 131-141.

Abednego, M.P., Ogunlana, S.O., 2006. Good project governance for proper risk allocation in public-private partnerships in Indonesia. International Journal of Project Management, 24, 622-634.

APM, 2012. APM Body of Knowledge (6th Edition). Association for Project Management, Bucks, UK.

Artto, K., Kujala, J., Dietrich, P., Martinsuo, M., 2008. What is project strategy? International Journal of Project Management, 26, 4-12.

Artto, K., Kulvik, I., Poskela, J., Turkulainen, V., 2011. The integrative role of the project management office in the front end of innovation. International Journal of Project Management, 29, 408-421.

ASX, 2007. Corporate governance principles and recommendations ASX Corporate Governance Council.

Atkinson, R., 1999. Project management: cost, time and quality, two best guesses and a phenomenon, its time to accept other success criteria. International Journal of Project Management, 17, 337-342.

Aubry, M., Richer, M.C., Lavoie-Tremblay, M., 2013. Governance performance in complex environment: The case of a major transformation in a university hospital. International Journal of Project Management.

Aubry, M., Richer, M.C., Lavoie-Tremblay, M., Cyr, G., 2011. Pluralism in PMO performance: The case of a PMO dedicated to a major organizational transformation. Project Management Journal.

Baker, G., Gibbons, R., Murphy, K.J., 2002. Relational Contracts and the Theory of the Firm. The Quarterly Journal of Economics, 117, 39-84.

Baldauf, J.R.B., Kaplan, R.B., 2011. Australian applied linguistics in relation to international trends. Australian Review of Applied Linguistics, 33, 04.01-04.32.

Bevir, M., 2010. The SAGE Handbook of Governance, in: Bevir, M. (Ed.). Sage, London.

Blair, M.M., 1995. Ownership and control: Rethinking corporate governance for the twentyfirst century. Brookings Institution Press.

Blomquist, T., Müller, R., 2006. Practices, roles, and responsibilities of middle managers in program and portfolio management. Project Management Journal, 37, 52-66.

Bosch-Sijtsema, P.M., Postma, T.J.B.M., 2010. Governance factors enabling knowledge transfer in interorganisational development projects. Technology Analysis and Strategic Management, 22, 593-608.

Bredillet, C.N., 2007. Exploring Research in Project Management: Nine Schools of Project Management Research (Part 3). Project Management Journal, 38, 2-4.

Bredillet, C.N., 2008a. Exploring Research in Project Management: Nine Schools of Project Management Research (Part 4). Project Management Journal, 39, 2-6.

Bredillet, C.N., 2008b. Exploring Research in Project Management: Nine Schools of Project Management Research (Part 5). Project Management Journal, 39, 2-4.

Bredillet, C.N., 2008c. Exploring Research in Project Management: Nine Schools of Project Management Research (Part 6). Project Management Journal, 39, 2-5.

Campbell, C., Pitt, L.F., Parent, M., Berthon, P.R., 2011. Understanding consumer conversations around ads in a Web 2.0 world. Journal of Advertising, 40, 87-102.

Chiles, T.H., McMackin, J.F., 1996. Integrating variable risk preferences, trust, and transaction cost economics. Academy of Management Review, 21, 73-99.

Cicmil, S., 1999. An insight into management of organisational change projects. Journal of workplace learning, 11, 5-15.

Clarke, T., 2004. Theories of corporate governance. Routledge New York. 
Clegg, S.R., Pitsis, T.S., Rura-Polley, T., Marosszeky, M., 2002. Governmentality Matters: Designing an Alliance Culture of Inter-organizational Collaboration for Managing Projects. Organization Studies, 23, 317.

Dann, S., 2010. Redefining social marketing with contemporary commercial marketing definitions. Journal of Business Research, 63, 147-153.

Davis, J.H., Schoorman, F.D., Donaldson, L., 1997. Toward a Stewardship Theory of Management. Academy of Management Review, 22, 20-47.

Donaldson, L., Davis, J.H., 1991. Stewardship theory or agency theory: CEO governance and shareholder returns. Australian Journal of management, 16, 49-64.

Donaldson, T., Preston, L.E., 1995. The stakeholder theory of the corporation: Concepts, evidence, and implications. Academy of Management Review, 20, 65-91.

Eccles, R.G., 1981. The quasifirm in the construction industry. Journal of Economic Behavior \& Organization, 2, 335-357.

Eisenhardt, K., 1989. Agency theory: An assessment and review. Academy of Management Review, 57-74.

Engwall, M., 2003. No project is an island: linking projects to history and context. Research Policy, 32, 789-808.

Eskerod, P., 1996. Meaning and action in a multi-project environment. Understanding a multi-project environment by means of metaphors and basic assumptions. International Journal of Project Management, 14, 61-65.

Foss, N.J., Husted, K., Michailova, S., 2010. Governing knowledge sharing in organizations: Levels of analysis, governance mechanisms, and research directions. Journal of Management Studies, 47, 455-482.

Freeman, R.E., Reed, D.L., 1983. Stockholders and Stakeholders: A New Perspective on Corporate Governance. California management review, 25.

Garland, R., 2009. Project Governance: A practical guide to effective project decision making. Buy now from Kogan Page.

Hällgren, M., 2012. The construction of research questions in project management. International Journal of Project Management, 30, 804-816.

Hillman, A.J., Dalziel, T., 2003. Boards of directors and firm performance: Integrating agency and resource dependence perspectives. Academy of Management Review, 28, 383-396.

Hodgson, D., Cicmil, S., 2006. Making Projects Critical (Management, Work and Organisations). Palgrave Macmillan, New York, NY.

Hodgson, D., Cicmil, S., 2008. The other side of projects: the case for critical project studies. International Journal of Managing Projects in Business, 1, 142-152.

Jensen, C., Johansson, S., Löfström, M., 2006. Project relationships - A model for analyzing interactional uncertainty. International Journal of Project Management, 24, 4-12.

Jensen, M.C., Meckling, W.H., 1976. Theory of the firm: Managerial behavior, agency costs and ownership structure. Journal of financial economics, 3, 305-360.

Jones, T.M., Wicks, A.C., 1999. Convergent stakeholder theory. Academy of Management Review, 24, 206-221.

Liesch, P.W., Håkanson, L., McGaughey, S.L., Middleton, S., Cretchley, J., 2011. The evolution of the international business field: a scientometric investigation of articles published in its premier journal. Scientometrics, 88, 17-42.

London, K., Siva, J.P.S., 2011. The role of reflexive capability in relation to intellectual capital on multi international partnerships. International Journal of Project Management, 29, 846-855.

Martin, N.J., Rice, J.L., 2007. Profiling enterprise risks in large computer companies using the Leximancer software tool. Risk Management, 9, 188-206.

Mason, C., Kirkbride, J., Bryde, D., 2007. From stakeholders to institutions: the changing face of social enterprise governance theory. Management Decision, 45, 284-301. 
Mathies, C., Burford, M., 2011. Customer service understanding: gender differences of frontline employees. Managing Service Quality, 21, 636-648.

Morris, P.W.G., 1997. The management of projects. Thomas Telford Services Ltd.

Müller, R., 2009. Project governance. Gower Publishing, Ltd.

Müller, R., Andersen, E.S., Kvalnes, O., Shao, J., Sankaran, S., Rodney Turner, J., Biesenthal, C., Walker, D., Gudergan, S., 2013. The interrelationship of governance, trust, and ethics in temporary organizations. Project Management Journal, 44, 26-44.

Nielsen, B.B., 2010. Strategic fit, contractual, and procedural governance in alliances. Journal of Business Research, 63, 682-689.

O'leary, M.B., Mortensen, M., Woolley, A.W., 2011. Multiple team membership: A theoretical model of its effects on productivity and learning for individuals and teams. Academy of Management Review, 36, 461-478.

O'Leary, T., 2012. Decision-Making in Organisations, in: Williams, T.M., Samset, K. (Eds.), Project Governance: Getting Investments Right. Palgrave Macmillan, Houndmills.

O'Leary, T., Williams, T., 2012. Managing the Social Trajectory: A Practice Perspective on Project Management. IEEE Transactions on Engineering Management, 99, 1-15.

OECD, 2004. Organisation for Economic Co-operation Development - Principles of Corporate Governance. OECD Publishing.

Oliver, C., 1991. Strategic responses to institutional processes. Academy of Management Review, 16, 145-179.

Pemsel, S., Müller, R., 2012. The governance of knowledge in project-based organizations. International Journal of Project Management, 30, 865-876.

Pfeffer, J., 2007. A modest proposal: How we might change the process and product of managerial research. Academy of Management Journal, 50, 1334-1345.

Pfeffer, J., Salancik, G.R., 1978. The external control of organizations: A resource dependence perspective. Stanford University Press, Stanford, California.

Piattoni, S., 2010. The theory of multi-level governance: conceptual, empirical, and normative challenges. Oxford University Press, Oxford.

PMI, 2013. A Guide to the Project Management Body of Knowledge (PMBOK Guide) - Fifth Edition. Project Management Institute, Newtown Square, Pennsylvania.

Pollack, J., 2007. The changing paradigms of project management. International Journal of Project Management, 25, 266-274.

Poppo, L., Zenger, T., 2002. Do formal contracts and relational governance function as substitutes or complements? Strategic management journal, 23, 707-725.

Roe, M.J., 2003. Political determinants of corporate governance: political context, corporate impact. Oxford University Press on Demand.

Rooney, D., 2005. Knowledge, economy, technology and society: the politics of discourse. Telematics and Informatics, 22, 405-422.

Scott, N., Smith, A.E., 2005. Use of automated content analysis techniques for event image assessment. Tourism Recreation Research, 30, 87-91.

Singh, J., Sirdeshmukh, D., 2000. Agency and trust mechanisms in consumer satisfaction and loyalty judgments. Journal of the Academy of Marketing Science, 28, 150-167.

Smith, A.E., Humphreys, M.S., 2006. Evaluation of unsupervised semantic mapping of natural language with Leximancer concept mapping. Behavior Research Methods, 38, 262279.

Söderlund, J., 2004. Building theories of project management: past research, questions for the future. International Journal of Project Management, 22, 183-191.

Söderlund, J., 2011. Pluralism in project management: navigating the crossroads of specialization and fragmentation. International Journal of Management Reviews, 13, 153-176. Stinchcombe, A.L., 1959. Bureaucratic and craft administration of production: A comparative study. Administrative Science Quarterly, 168-187. 
Stoker, G., 1998. Governance as theory: five propositions. International social science journal, 50, 17-28.

Sydow, J., Lindkvist, L., DeFillippi, R., 2004. Project-Based Organizations, Embeddedness and Repositories of Knowledge: Editorial. Organization Studies, 25, 1475-1489.

Thompson, J.D., 2011. Organizations in action: Social science bases of administrative theory. McGraw-Hill, New York.

Turner, J.R., 2006. Towards a theory of project management: The nature of the project governance and project management. International Journal of Project Management, 24, 93-95. Turner, J.R., 2009. The handbook of project-based management. McGraw-Hill, London.

Turner, J.R., Keegan, A., 2001. Mechanisms of governance in the project-based organization: Roles of the broker and steward. European Management Journal, 19, 254-267.

Turner, R.J., Huemann, M., Anbari, F.T., Bredillet, C.N., 2010. Perspectives on projects. Routledge, Abingdon, Oxon.

Weaver, P., 2005. Effective project governance-A cultural sea change, Proceedings of, PMI Global Congress-Asia Pacific, Singapore.

White, H.D., Griffith, B.C., 1981. Author cocitation: A literature measure of intellectual structure. Journal of the American Society for information Science, 32, 163-171.

Williams, T.M., Samset, K., 2012. Project Governance: Getting Investments Right. Palgrave Macmillan.

Williamson, O., 1998. Transaction cost economics: how it works; where it is headed. De Economist, 146, 23-58.

Williamson, O.E., 1975. Markets and hierarchies. New York, 26-30.

Williamson, O.E., 1979. Transaction-cost economics: the governance of contractual relations. Journal of Law and Economics, 22, 233.

Williamson, O.E., 1988. Corporate finance and corporate governance. The journal of finance, 43, 567-591.

Winch, G.M., 2001. Governing the project process: A conceptual framework. Construction Management and Economics, 19, 799-808.

Zaheer, A., McEvily, B., Perrone, V., 1998. Does trust matter? Exploring the effects of interorganizational and interpersonal trust on performance. Organization Science, 9, 141-159.

Zaheer, A., Venkatraman, N., 1995. Relational governance as an interorganizational strategy: An empirical test of the role of trust in economic exchange. Strategic management journal, $16,373-392$. 